\title{
Diocese de Viana - Maranhão: disputas de poder nos bispados de Dom Hélio Campos e Dom Adalberto Paulo da Silva
}

\section{Eliane Ramira Sousa Lopes ${ }^{1}$}

RESUMO: O estudo objetivou analisar as relações Igreja/ Estado, a partir das práticas dos bispos Dom Francisco Hélio Campos (1969-1975) e Dom Adalberto Paulo da Silva (1975-1995) na Diocese de Viana, entendendo que ambos carregaram em seus valores e práticas religiosas elementos de reiteração e/ou conflitos com essas orientações institucionais e disputas políticas que marcam o posicionamento da igreja no período da ditadura. Assim, com a intenção de abarcar a atuação dos dois bispos, fez-se o recorte temporal de 1969 a 1985. Em termos específicos, a pesquisa averiguou as visões dos bispos Dom Hélio Campos e Dom Adalberto Paulo da Silva sobre Igreja/ doutrina e seu papel, descrevendo a atuação e posicionamentos políticos e religiosos dos bispos na Diocese de Viana; analisou-se as visões dos religiosos sobre a política do país. No campo metodológico utilizou-se a pesquisa documental a partir de arquivos disponíveis no campo empírico - o Arquivo Público Estadual do Maranhão, onde encontrou-se documentações acerca da atuação do clero de Viana. Foram pesquisados, sobretudo, os arquivos da Delegacia de Ordem Política e Social do Maranhão (DOPS-MA). Além dos arquivos da DOPS, outro campo pesquisado foi a Comissão Pastoral da Terra (CPT). Fez-se também entrevistas com 10 agentes ligados diretamente ou indiretamente com os trabalhos dos bispos. Percebeu-se como se construiu reconhecimento de cada bispo tanto na diocese de Viana como no Estado através de práticas de poder.

Palavras-chave: Bispos. Estado. Igreja. Poder.

\section{Diocese of Viana - Maranhão: power disputes in the bishoprics of Dom Hélio Campos and Dom Adalberto Paulo da Silva}

\begin{abstract}
The study aimed to analyze Church / State relations, based on the practices of bishops Dom Francisco Hélio Campos (1969-1975) and Dom Adalberto Paulo da Silva (1975-1995) in the diocese of Viana, understanding that both carried in their values and practices Religious elements of reiteration and / or conflicts with these institutional orientations and political disputes that mark the position of the church in the period of dictatorship. Thus, with the intention of encompassing the work of the two bishops, the temporal cut was made from 1969 to 1985 . In specific terms, the research investigated the views of bishops Dom Hélio Campos and Dom Adalberto Paulo da Silva on Church / doctrine and its Describing the performance and political and religious positions of the bishops in the diocese of Viana; The religious views on the politics of the country were analyzed. In the methodological field the documentary research was used from the archives available in the empirical field - the State Public Archive of Maranhão, where documents were found about the work of the clergy of Viana. The archives of the Political and Social Order Office of Maranhão (DOPS-MA) were searched. In addition to the DOPS files, another field was the Pastoral Land Commission (CPT). There were also interviews with 10 agents directly or indirectly connected with the work of the bishops. It was realized how the recognition of each bishop was built both in the diocese of Viana and in the State through practices of power.
\end{abstract}

Keywords: Bishops. State. Church. Power.

- Enviado em 01/05/2017

- Aprovado em 17/05/2017

1 Graduada e Mestra em Ciências Sociais pela Universidade Federal do Maranhão. Email: ramirareluz@hotmail.com 


\section{INTRODUÇÃO}

A Igreja Católica no Brasil, no decorrer de sua história, passou por grandes transformações em seu interior, que resultaram de conflitos internos e externos, particularmente em suas relações com o Estado. As origens desses conflitos repousam, entre outros elementos, na pluralidade de interpretações sobre a própria igreja, seus fundamentos, formas de professar a fé e as articulações entre esta e a política. A partir dessas diferentes visões emergiram práticas diferenciadas, algumas das quais desencadearam movimentos religiosos - sociais - políticos, além de di-visões ${ }^{2}$ internas, entre progressistas e conservadores, predominante desde os anos 1960.

Este setor progressista é entendido como um elemento que incorpora a questão dos direitos sociais, e que se mobiliza politicamente, através de organismos como as Comunidades Eclesiais de Base (CEB's) e as pastorais sociais ${ }^{3}$, visto que reivindicava a abertura política a setores populares, justiça social e baseia-se em princípios da solidariedade e conquista de direitos. Esse setor recomenda "a formação de grupos cristãos militantes, objetivando dar sua ajuda a programas e desenvolvimento comunitário (educação, organização de cooperativas e outros)" (KRUWIEDE, 1971 apud SCHERER- WARREN, 1996, p.36). Sob esse ponto, ao referir-se a setor progressista da Igreja, estar-se reportando a um segmento heterogêneo, que defende ações políticas no combate aos problemas sociais, uma parcela ativista - se inseriam em congregações juntando freiras, freis, padres e bispos- da igreja que busca proximidade com os setores populares (LOPES, 2013).

Nesse sentido, estes setores da Igreja Católica começam a se voltar aos problemas sociais no campo, como já vinha acontecendo com trabalhadores urbanos e o setor estudantil, tornando recorrente o envolvimento de padres, freiras e bispos com os problemas da população rural empobrecida, subalternizadas pelo sistema capitalista.

\footnotetext{
${ }^{2}$ Utiliza-se a expressão di-visão remetendo a visão de mundo e visão de campo de poder.

${ }^{3}$ São serviços específicos a categorias de pessoas e/ou situações também específicas da realidade social. Constituem ações voltadas concretamente para os diferentes grupos ou diferentes facetas da exclusão social (CARTILHAS, 2001, p.8).
} 
Assim, desde o fim dos anos de 1950, a Igreja Católica passou a desenvolver ações no interior do país com os trabalhadores do campo, a chamada educação popular, desenvolvida a partir do método Paulo Freire e institucionalizada em 1961 pelo presidente Jânio Quadro e o arcebispo de Aracajú, Dom José Távora, sob o nome de Movimento de Educação de Base (MEB), o qual propunha não somente a alfabetização dos trabalhadores rurais, como também suas inserções no campo social e político, promovendo assim transformações sociais.

No Maranhão, as atividades educativas promovidas pelo MEB aconteceram paralelamente aos trabalhos da União dos Lavradores e Trabalhadores Agrícolas do Brasil (ULTAB), entidade que buscava organizar os trabalhadores rurais Ihes oferecendo condições de mobilizações em vista de salários e reforma agrária. A ULTAB, na década de 50, coordenou lutas pela reforma agrária, uma vez que, o sindicalismo rural no Maranhão não era mobilizado. Neste cenário, a setor progressista da Igreja Católica passa a se engajar em sindicatos dispondo aos trabalhadores uma pedagogia em que o "povo" é considerado "sujeito de sua própria história" (ALMEIDA, 1981; SEMERARO, 1994).

Bispos de várias regiões preocupados com assuntos concernentes ao desenvolvimento e a reforma agrária, se articularam com o governo federal, assim, a pedido da CNBB, o presidente Juscelino Kubitschek (1955-1960) realizou encontros com o episcopado do Nordeste (Campina Grande, 1955 e Natal, 1959), onde se discutiram a criação, da Superintendência do Desenvolvimento do Nordeste (SUDENE), criada em 1959, pode ser considerada como um produto da cooperação entre Igreja e Estado. Entre 1961 e 1964, a Igreja Católica intensifica seu envolvimento com a reforma agrária, esta instituição religiosa que durante toda sua história no país concentrou-se prioritariamente às classes dominantes, passou a voltar-se aos problemas da massa e de setores mais pauperizados. Esse deslocamento das posições, a princípio fragmentado e espontâneo, se fortaleceu com as práticas dos grupos da esquerda católica, gerados na vanguarda da Ação Católica Brasileira (ACB), especificadamente, em seus setores especializados (MAINWARRING, 2004, SEMERARO, 1994).

Considere-se, ademais, elementos exógenos ao catolicismo brasileiro que reforçava o setor reformista, no caso a ascensão ao papado de João XXIII, a quem católicos conservadores reputavam como "esquerdista". Apesar de ter sido um pontificado curto (1958-1963), João XXIII erigiu reformas através das encíclicas Mater et Magistra (1961), e Pacem in Terris (1963). Com a já consolidada Ação Católica (AC), este papa abriu precedentes para o fortalecimento da Ação Católica Especializada, como a Juventude Operária Católica (JOC), Juventude Agrária Católica (JAC), Juventude Universitária Católica (JUC) e outras. Entre suas posturas consideradas populares pela maioria, a mais marcante que transformou a história da Igreja Católica no mundo, sobretudo na América Latina, foi a convocação de um concílio ecumênico, o chamado 
Concílio Vaticano II, que "reafirmou com veemência a ideia de uma Igreja de serviço e não de poder" (GUTIÉRREZ, 1983), oportuno para setores progressistas ganharem fôlego nas práticas sociais, unindo fé e política.

Um elemento influenciador nas tomadas de posições progressistas de diversos religiosos, o Concílio do Vaticano II, de 1962-1965, a Conferência Episcopal Latino Americano em Medellín, em 1968 e a Conferência de Puebla em 1979, demarcam uma guinada aos trabalhos pastorais que enfatizavam a "opção pelos pobres". Scott Mainwaring (2004) avalia que as transformações vinculadas à fé e a justiça social durante esses acontecimentos foram alcançadas no Brasil como jamais anteriormente no catolicismo internacional.

Nessa configuração social, a Conferência Nacional dos Bispos do Brasil (CNBB), no ano de 1962, enfatiza a ideia da Igreja se voltar ao sindicalismo rural. Porém, o projeto de aproximação desta instituição religiosa com a massa trabalhadora rural, engajadas nas lutas por reforma agrária, não obteve o êxito esperado, mesmo com intensas mobilizações políticas, pois para muitos camponeses a Igreja acendia velas tanto para a massa de trabalhadores rurais como para os latifundiários (ALMEIDA, 1981).

Foi nesse contexto que a Conferência Nacional dos Bispos do Brasil (CNBB) reviu sua atuação perante o movimento da massa de camponeses, o que levou à fundação de sindicatos, conhecidos como sindicatos dos padres. Religiosos engajam-se em mobilizações das organizações sindicais, oferecendo aos trabalhadores rurais além da criação de novos sindicatos com o trabalho, educação sindical com formação de lideranças, tudo isso a partir do Movimento de Educação de Base (MEB).

No interior do Maranhão, no início dos anos 1960, essas mobilizações de organizações sindicais rurais, realizaram-se por meio do MEB, juntamente com as pastorais sociais e as Comunidades Eclesiais de Base (CEB's) oferecendo regularmente formações de lideranças sindicais aos trabalhadores do campo, em razão de que eram recorrentes as disputas de terras entre posseiros e grileiros, como também a exploração sobre os lavradores.

Através do MEB, alguns religiosos iniciaram os primeiros cursos de lideranças sindicais no campo, nas cidades de Itapecuru, Viana e também em São Luís. Conforme Almeida (1981) foi registrado no ano de 1962, o treinamento, em São Luís, de 20 (vinte) lideranças camponesas das cidades de Matinha, Pirapemas, Colinas, Viana, Pindaré - Mirim e Cantanhede, por meio do MEB. A essa altura, já fazia-se claro para muitos religiosos, sobretudo padres e bispos, a gravidade dos problemas do campo como uma questão a ser combatida, dado ser grande a desigualdade social; alguns bispos passaram a ser apontados como líderes de movimentos sociais do campo. 
Antes do golpe, o MEB se destacou com experiências em educação e cultura popular, promovendo atividades que estimulavam as transformações sociais, após o golpe sofreu repressão por parte do Estado, foi gradualmente marginalizado por bispos, encerrando assim, as atividades em 1967. Este movimento foi à primeira tentativa da Igreja Católica de desenvolver práticas pastorais transformadoras, uma vez que o analfabetismo e o elevado índice da população pauperizada figurava a realidade brasileira.

O regime ditatorial e, essa condição econômica e social, era uma conjuntura de grande parte da América Latina, o que levou teólogos brasileiros como Hugo Husmann, Leonardo Boff e Clodovis Boff, o peruano Gustavo Gutiérrez, o mexicano Enrique Dussel, e outros, a escreverem sobre a nova pedagogia existente na Igreja Católica, a chamada Teologia da Libertação (TL), inspirada também pelo debate teológico e político de instâncias da própria Igreja focado em reflexões sobre a práxis histórica do homem, na combinação entre ver, pensar/julgar e agir A TL nasceu como reflexão sobre a práxis e os compromissos assumidos pelos cristãos que interpretaram a realidade latino-americana em termos de dependência e a necessidade de libertação. Uma igreja que não reproduzisse as injustiças sociais, mas que oferecesse liberdade aos oprimidos (GUTIÉRREZ, 1983).

Ressalte-se que a Teologia da Libertação (TL) foi um movimento resultante da experiência de uma pastoral popular na América Latina; no Brasil este modelo de pastoral realizava-se recorrentemente pelas CEB's, com a pedagogia do MEB. "As Comunidades Eclesiais de Base formaram um tipo de organização que resistia e contestava a divisão de classes e as ditaduras que reinavam na América Latina" (PASSOS, 2006, p.16). Conforme Gutiérrez (1983) a Teologia da Libertação

é uma teologia da salvação nas condições concretas, históricas e políticas de hoje. Essas mediações históricas e políticas atuais, valorizadas por si mesmas, alteram a vivência e a reflexão sobre o ministério escondido desde todos os tempos e revelado agora, sobre o amor do pai e a fraternidade humana, sobre a salvação. Isso é o que se pretende significar na hora presente o termo (p.268).

Os setores progressistas da Igreja Católica, embora constantemente combatida pelo conservadorismo que desde a colonização do Brasil buscou meios de resguardar o status quo desta instituição religiosa, traçava pela primeira vez um catolicismo revolucionário, o mais radical de toda sua história. Essa realidade é condizente com os acontecimentos na América Latina, onde muitos países viviam sob regime ditatorial e empresas multinacionais dominando a economia e alavancando o desemprego em países como Argentina, Bolívia, Paraguai e Brasil. Em resposta às difíceis condições socioeconômicas e políticas do continente o setor progressista da Igreja católica, segundo Gutiérrez (1983), examina necessidade de mudanças face à "insustentável situação de miséria, alienação e espoliação em que vive a 
imensa maioria da população latino-americana" (p. 85). Acreditava que era preciso encontrar urgentemente meios de libertação econômica, social e política, levantando assim, uma bandeira de liberdade para a formação de uma nova sociedade. Essa ênfase dada ao engajamento político também é observada pela socióloga Suely Martins (2000), que identifica a teologia da libertação como:

um movimento intenso de relacionar fé e vida, fé e política. Tendo como instrumento de análise as ciências sociais, esta teologia rompe com a dualidade da fé como algo separado da vida, apresenta um Deus que faz história junto com o seu povo; conclama os pobres a serem protagonistas na história lutando pela libertação de tudo o que escraviza o homem, incluindo aí as estruturas injustas do capitalismo; faz uma leitura bíblica situada histórica e politicamente e reinterpretada à luz da realidade cotidiana das classes populares. Incentiva a organização popular, seja através de movimentos populares, sindicatos ou partidos (p.20).

Constata-se, então, que no início dos anos de 1960, as ações de religiosos progressistas imprimiram na Igreja Católica, especialmente no campo, uma face de igreja popular, a qual ganhou força com o Vaticano II (1962-1965) e posteriormente com a Teologia da Libertação (TL), cujas ações eram orientadas pelo princípio de "opção preferencial pelos pobres", visando à transformação social por meio de atividades voltadas a segmentos à margem da sociedade, como mulheres, negros e lavradores.

No entanto, esta opção não se fez sem custos políticos. No Brasil no início do período militar, setores conservadores do catolicismo foram às ruas apoiar a tomada do governo. Já nesse contexto, estas forças conservadores consideravam os progressistas, incluindo aí os religiosos, como um perigo à ordem social e política e que, por isso, deveriam ser, de algum modo, contidos. Já em fins dos anos 1960 os conflitos entre Igreja e Estado haviam se aprofundado e com a decretação do Ato Institucional № 5 (AI-5), em dezembro de 1968.

Esses conflitos já não envolvem apenas os progressistas ou religiosos de menor posição hierárquica, pois, desde esse período as agências estatais encarregadas da repressão já não viam nos templos ou na alta hierarquia religiosa um limite intransponível para as suas ações. Toda a Igreja, agora poderia ser alvo das políticas de repressão e controle perpetradas pelo Estado e nesse novo contexto, a Igreja católica passa de apoiadora à opositora do Estado de Exceção ${ }^{4}$ instaurado em 1964, estreitando-se ainda mais os laços entre católicos progressistas com movimentos sociais e demais setores sociais oprimidos pela violência e repressão do regime militar que, a essa altura, escancarara seu caráter ditatorial (ARNS, 1996; SERBIN, 2001).

\footnotetext{
${ }^{4}$ No estado de exceção a força existe a partir da suspensão da aplicação da lei, isto é, há uma força de lei sem lei, que legitima a violência com arbitrariedade e suspensão dos direitos, em que o executivo amplia seus poderes para a esfera legislativa em nome da segurança, a serviço da concentração de poder (AGAMBEN, 2004).
} 
Diante do exposto, $\mathrm{O}$ estudo objetivou analisar as relações Igreja/ Estado, a partir das práticas dos bispos Dom Francisco Hélio Campos (1969-1975) e Dom Adalberto Paulo da Silva (1975- 1995) na Diocese de Viana, entendendo que ambos carregaram em seus valores e práticas religiosas elementos de reiteração e/ou conflitos com essas orientações institucionais e disputas políticas que marcam o posicionamento da igreja no período da ditadura.

Assim, com a intenção de abarcar a atuação dos dois bispos, faz-se o recorte temporal de 1969 a 1985. Em termos específicos, a pesquisa averigua as visões dos bispos Dom Hélio Campos e Dom Adalberto Paulo da Silva sobre Igreja/ doutrina e seu papel, descrevendo a atuação e posicionamentos políticos e religiosos dos bispos na Diocese de Viana; analisa-se as visões dos religiosos sobre a política do país.

A delimitação espacial, cidade de Viana, decorre do fato de ser a Diocese de Viana considerada por órgãos de segurança (DOPS- MA) como "palco do clero progressista no Estado do Maranhão" ${ }^{5}$, embora as práticas ali desenvolvidas nesse período, no caso de um dos bispos, não ser considerado progressista. A análise desses dois casos permite\ examinar a diversidade de concepções de igreja entre os próprios religiosos, concretizadas em dois bispados bem diferentes no que concerne à interpretação dos princípios religiosos, relações com as hierarquias internas, com os fiéis, o Estado e organizações da sociedade civil.

No campo metodológico utiliza-se a pesquisa documental a partir de arquivos disponíveis no campo empírico - o Arquivo Público Estadual do Maranhão, onde encontrou-se documentações acerca da atuação do clero de Viana. Foram pesquisados, sobretudo, os arquivos da Delegacia de Ordem Política e Social do Maranhão (DOPS-MA). Além dos arquivos da DOPS, outro campo pesquisado foi a Comissão Pastoral da Terra (CPT). Além destes campos empíricos entrou-se em contato através de e-mail, com a secretaria da Conferência Nacional dos Bispos do Brasil (CNBB), em Brasília, solicitando documentos sobre o assunto no referido recorte temporal, entre 1969 a 1985.

No Maranhão, a DOPS (Delegacia de Ordem Política e Social) foi constituída em Junho de 1969 por transformação da Divisão de Ordem Política e Social em Delegacia. Em alguns estados brasileiros o DOPS se refere a Departamento de Ordem Política e Social, sendo conhecido também pela sigla DEOPS (Departamento Estadual de Ordem Política e Social) quando se tratava da polícia política de nível estadual, tal sigla foi existente no estado de São Paulo. No Maranhão a DOPS de acordo com o documento Memory of the World Register, da Unesco, se refere a:

\footnotetext{
${ }^{5}$ Informação no 064/ SI/DOPS/MA/1975 (Figura 4).
} 
Delegacia de Ordem Política e Social do Maranhão surgiu da transformação da Divisão de Ordem Política e Social em Delegacia, por meio da lei delegada n. 23, de 10 de junho de 1969. Em 30 de dezembro de 1991, ela foi extinta, conforme o artigo 4 o da lei n. 5.332. Teve suas funções definidas no regimento da Secretaria de Segurança, aprovado pelo decreto n. 4.077, de 12 de janeiro de 1970. Ficou subordinada ao Departamento de Segurança Pública/Divisão de Polícia Judiciária, com a competência de coletar, classificar e interpretar informações; arquivar documentos e informações reservadas ou secretas; apurar e processar informações penais relacionadas com a ordem política e social; organizar e manter atualizado o fichário individual de personalidades políticas sociais e de pessoas adeptas de ideologias proibidas pela Constituição Federal e por outras leis. (UNESCO, 2016, p. 57).

Tendo atuado ao longo de todo o período ditatorial, o momento de fechamento da DOPS-MA é um elemento que chama atenção, pois o marco convencionado como fim da ditadura é o ano de 1985, porém, este órgão tem a datação do seu fim no ano de 1991, o que aponta uma permanência dos registros daqueles que nesse período eram considerados como ameaças. Todavia, os estados brasileiros tiveram diferentes datações em relação à extinção do DOPS: no Rio Grande do Sul, por exemplo, ocorreu ainda na ditadura, em 1982, com a incineração de todos os documentos, contudo, em decorrência das articulações dos órgãos de informações e do estado ter filiais chamadas Supervisões de Ordem Política e Social (SOPS), foi possível reconstituir as documentações do DOPS-RS; já em São Paulo, o DEOPS-SP, o qual teve a polícia política que mais monitorou e torturou "inimigos" do regime, inclusive, a que mais perseguiu, registrou, torturou e matou religiosos, permaneceu na ativa até 1983 , com seu fim ainda na ditadura, o que demonstra a relativa autonomia dos órgãos de segurança e informações conforme avaliado por Evaristo Arns e José Murilo de Carvalho (ARNS, 1996; AZEVEDO, 2012; BAUER, 2006; CARVALHO, 2004).

Nota-se que o tempo de institucionalização da DOPS-MA contempla o período da pesquisa, no entanto, neste acervo não se encontrou arquivos referentes aos anos de 1969 a 1971 relacionados à Viana, assim como na CPT e CNBB não se encontrou arquivos referentes aos anos de 1969 a 1974. Em relação à CPT, compreende-se pela sua institucionalização se efetivar em 1975, abarcar documentos somente a partir desta data, deixando de contemplar, portanto, todo o período de um dos bispados investigados na presente pesquisa, no caso, fica de fora o período de D. Hélio Costa e é contemplado apenas o de Dom Adalberto. A CNBB, por sua vez, apresentou documentos que remontam a 1963, ano da formação da Diocese de Viana, e documentação a partir de 1975 quando a chegada de Dom Adalberto desencadeou muitos conflitos entre os religiosos e entre estes e segmentos organizados da comunidade local. 
Essa ausência de documentos na DOPS - MA remete ao que Castro (2008) pondera sobre a necessidade de se compreender a constituição dos conjuntos de documentos que compõem um arquivo, que, necessariamente, implica em diversos processos seletivos: seleções e classificações do próprio autor, de quem "recupera", de quem organiza, dos critérios de localização e publicação. Fatores externos também impactam a construção de arquivos, como o ambiente de liberdade ou censura, que impactam nas condições de produção e guarda de documentos. Assim, a decretação do Al-5, em dezembro de 1968, pode efetivamente, ter ocasionado inibições ou perdas de documentos produzidos pelos críticos ao regime, ao passo que aqueles produzidos e preservados pelas agências estatais, como a DOPS, devem ser interpretados como instrumentos da "guerra" que essas agências realizavam contra seus oponentes, que eram monitorados.

Diante destas questões tem-se trabalhado com as informações disponíveis, mas atentos às lacunas e silêncios, os documentos da DOPS-MA foram avaliados "como parte de um conjunto e não apenas como peças únicas da evidência" (CASTRO, 2008, p.55-56), ou seja, foi levada em consideração a articulação da DOPS-MA com os demais órgãos que compunham o SNI, o que culminou um conjunto de documentos sobre a Diocese de Viana e a relação desses documentos com relatos obtidos através de fontes orais.

A pesquisa, que seria toda conduzida com fontes documentais, foi redefinida após inserção do pesquisador no campo e constatação de que não existiam documentos que contemplassem os três primeiros anos $(1969,1970$ e 1971) da investigação. Assim, outras fontes de dados foram acionadas, entre estas, a realização de entrevistas com pessoas envolvidas direta ou indiretamente com a questão em estudo. Em face dessa estratégia, impunha-se lidar com esta ferramenta metodológica com cautelas análogas àquelas dispensadas aos documentos. No caso das entrevistas, buscou-se levar em consideração que neste tipo de relação, há uma interpretação do entrevistado por aquilo que é pesquisado e a ideia da pesquisa que o entrevistador tem em mente; assim o pesquisador deve "tentar reduzir as distorções que dela resultam, ou, pelo menos, compreender o que pode ser dito e o que não pode, as censuras que o impedem de dizer certas coisas e as incitações que encorajam a acentuar outras" (BOURDIEU, 2007, p.695).

A partir desta compreensão foram realizadas onze entrevistas, considerando as informações como elementos de reconstruções oriundas dos pontos de vista dos entrevistados, buscando dar conta dos mesmos e lhes oferecendo certa liberdade de respostas dentro dos limites das perguntas (POUPART, 2008). 


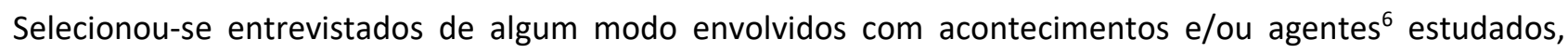
compondo-se um quadro de onze entrevistados, que inclui: freira (01), padres (04), seminarista (01), sindicalista/lavrador (01), leigos (03), além de um dos bispos pesquisados, que ainda está vivo e aceitou o pedido de entrevista. A lista de entrevistados se formou com a inserção da autora no Instituto de Estudos Superiores do Maranhão - Faculdade Católica (IESMA), onde obteve contado de dois ex-alunos e de um Padre Professor, os quais acionaram suas redes de relações sociais viabilizando assim, os contatos com a pesquisadora.

Quanto à forma de realização das entrevistas, importa registrar que houve grande variação, decorrente das diferentes condições de acessibilidade aos entrevistados. Assim, algumas foram feitas através de e-mail e Skype, com padres italianos residentes atualmente na Itália; por telefone, com a freira de Peritoró-MA e um bispo, que, atualmente, reside em Fortaleza e não utiliza e-mail ou similar. As demais entrevistas foram feitas presencialmente, com utilização de gravador. Das dificuldades de acesso advieram dificuldades de obtenção do termo de consentimento para os usos das informações, daí, optou-se, por esses casos, por trabalhar com as informações preservando o anonimato das fontes, identificando os entrevistados apenas pela posição religiosa ou social que ocupava no período em foco (padre, freira, leigo, seminarista e lavrador/sindicalista), seguido de respectiva numeração: padre 01, padre 02; padre 03 e padre 04; leigo 01, leigo 02 e leigo 03.

Cabe destacar que as entrevistas apresentadas se referem a eventos transcorridos aproximadamente há cinquenta anos, o que exige cuidados na interpretação dessas narrativas. A respeito de relatos que remetem à memória, o sociólogo francês Halbwachs (1968) os compreende como uma experiência constituída por um processo de diálogos entre diferentes pontos de vista, tanto atuais quanto do passado, que de alguma forma, estão presentes para o indivíduo. As experiências do passado dos entrevistados podem ser vistas, assim, sob diferentes pontos de vista. Este mesmo autor avalia que a história do passado não é toda do passado, nem aquilo que restou dele, mas uma história viva que se perpetua ou se renova através do tempo. A partir desta ideia conduziu-se as entrevistas.

\footnotetext{
${ }^{6}$ Nesse estudo "agente" e "indivíduo" serão tratados como correlatos, sendo que agentes também se referirá a um coletivo, dado ao contexto.
} 
Quadro: Perfil dos entrevistados

\begin{tabular}{|c|c|c|c|c|c|}
\hline $\begin{array}{l}\text { NOME } \\
\text { FICTÍCIO }\end{array}$ & $\begin{array}{l}\text { POSIÇÃO SOCIAL E } \\
\text { NACIONALIDADE }\end{array}$ & ÁREA DE ATUAÇÃO & $\begin{array}{l}\text { BISPADO DE } \\
\text { REFERÊNCIA }\end{array}$ & SEXO & $\begin{array}{l}\text { FAIXA } \\
\text { ETÁRIA }\end{array}$ \\
\hline Padre 01 & $\begin{array}{l}\text { Padre } \\
\text { (Italiano) }\end{array}$ & $\begin{array}{l}\text { Paróquia de Bom } \\
\text { Jardim }\end{array}$ & $\begin{array}{l}\text { Dom Hélio } \\
\text { Dom Adalberto }\end{array}$ & Masculino & 75 anos \\
\hline Padre 02 & $\begin{array}{l}\text { Padre } \\
\text { (Italiano) }\end{array}$ & $\begin{array}{l}\text { Paróquia São } \\
\text { Vicente Ferrer }\end{array}$ & $\begin{array}{l}\text { Dom Hélio } \\
\text { Dom Adalberto }\end{array}$ & Masculino & 79 anos \\
\hline Padre 03 & $\begin{array}{l}\text { Padre e } \\
\text { Educador Popular } \\
\text { (Belgo) }\end{array}$ & $\begin{array}{l}\text { CPT e CEB's (São } \\
\text { Vicente Ferrer e } \\
\text { São João Batista) }\end{array}$ & Dom Adalberto & Masculino & 74 anos \\
\hline Padre 04 & $\begin{array}{l}\text { Padre } \\
\text { (Brasileiro/ } \\
\text { Viana- MA) }\end{array}$ & $\begin{array}{l}\text { Paróquias de São } \\
\text { Vicente de Ferrer, } \\
\text { São João Batista, } \\
\text { Cajapió e São } \\
\text { Bento de } \\
\text { Bacurituba }\end{array}$ & $\begin{array}{l}\text { Dom Hamleto } \\
\text { D'Angelis }\end{array}$ & Masculino & 88 anos \\
\hline Seminarista & $\begin{array}{l}\text { Seminarista } \\
\text { Brasileiro / Matinha - } \\
\text { MA) }\end{array}$ & $\begin{array}{l}\text { Estudante do } \\
\text { Seminário }\end{array}$ & Dom Adalberto & Masculino & 54 anos \\
\hline Freira & $\begin{array}{l}\text { Freira } \\
\text { (São Vicente Ferrer- } \\
\text { MA) }\end{array}$ & $\begin{array}{l}\text { Catequista } \\
\text { (Congregação } \\
\text { Missionária Filha } \\
\text { de Jesus } \\
\text { Crucificado) }\end{array}$ & Dom Adalberto & Feminino & 70 anos \\
\hline Leigo 01 & $\begin{array}{l}\text { Estudante } \\
\text { (Brasileiro/ } \\
\text { Viana- MA) }\end{array}$ & $\begin{array}{l}\text { Pastoral da } \\
\text { Juventude }\end{array}$ & Dom Hélio & Masculino & 63 anos \\
\hline Leigo 02 & $\begin{array}{l}\text { Educador Popular e } \\
\text { Vereador } \\
\text { (Brasileiro/ } \\
\text { Viana- MA) }\end{array}$ & $\begin{array}{l}\text { Pastoral de } \\
\text { Juventude }\end{array}$ & $\begin{array}{l}\text { Dom Hélio e de } \\
\text { Dom Adalberto }\end{array}$ & Masculino & 84 anos \\
\hline Leigo 03 & Educadora Popular & Cáritas e CPT & Dom Adalberto & Feminino & 60 anos \\
\hline
\end{tabular}

${ }^{7}$ Esta referência não significa atuação direta no bispado, mas se vincula ao período que o entrevistado acompanhou mais de perto. 


\begin{tabular}{|l|l|l|l|l|l|}
\hline & $\begin{array}{l}\text { (Brasileiro/ } \\
\text { Viana- MA) }\end{array}$ & & & & \\
\hline Sindicalista & Lavrador & $\begin{array}{l}\text { Sindicato dos } \\
\text { trabalhadores rural }\end{array}$ & $\begin{array}{l}\text { Dom Hélio e de } \\
\text { Dom Adalberto }\end{array}$ & Masculino & $\begin{array}{l}\text { Entre 60- } \\
70 \text { anos }\end{array}$ \\
\hline Bispo & $\begin{array}{l}\text { Bispo } \\
\text { (Brasileiro/ } \\
\text { Sambaíba- MA) }\end{array}$ & $\begin{array}{l}\text { Toda Diocese de } \\
\text { Viana }\end{array}$ & Dom Adalberto & Masculino & 87 anos \\
\hline
\end{tabular}

Fonte: Organizado pela Autora

Como referencial teórico metodológico a conduzir a pesquisa e a análise optou-se pela abordagem sociológica de Norbert Elias em seus estudos sobre a concepção de poder, caracterizado como elemento constitutivo de todas as relações entre os indivíduos, atuando não apenas nas relações com o Estado, mas também nas inter-relações humanas em configurações sociais específicas e com variáveis níveis de flexibilidade e rede de interdependências complexas. Utiliza-se de sua análise relacional como norteadora desta pesquisa, objetivando entender como se constituíram as interações dos dois bispos com as instâncias religiosas e com a comunidade local. Ressalta-se que no primeiro bispado (1969-1975), embora transcorrido no período de repressão mais violenta, o líder religioso assumiu os riscos de contrapor-se à ordem vigente e associou-se aos trabalhadores rurais em suas lutas e reivindicações à época consideradas subversivas e comunistas. Já o segundo bispado, transcorrido em período caracterizado como de "transição democrática" (pós 1975), desenvolvia atividades mais voltadas à religiosidade dos sacramentos, liturgias e orações, bem como frear a atuação política da Igreja e suas alianças com organizações populares.

Elias (1993), a partir de uma perspectiva de historicização discorre sobre noção de poder, avalia a formação de Estado, onde uma série de processos leva a um processo civilizador em que os indivíduos internalizam regras sociais e atingem um padrão. Com tensões em meio às transformações, as configurações nesse processo vão se formando uma em relação às outras, havendo um equilíbrio de poder dos indivíduos no jogo. Sob o mesmo ponto de historicização e de uma sociologia relacional em que um só é entendido a partir do outro, pode-se entender a construção de campo de Bourdieu (2003), o qual se refere ao local onde se objetivam os conflitos, as tensões, onde ocorrem práticas específicas de agentes também específicos e sob regras específicas, não existindo sem os agentes e os agentes não existem sem o campo. A partir desta perspectiva, verificou-se as práticas dos religiosos em Viana, que através de suas 
propriedades, de suas redes de relações constroem um reconhecimento, uma objetivação no campo religioso, em que os bispos e demais religiosos em suas competências específicas sob as orientações do Vaticano II e suas interpretações sobre o mais legítimo modo de ser igreja, apresentam suas tomadas de posição no campo, que é atravessado por lutas específicas e é historicamente construído.

Não se pretende fazer uma análise exaustiva a partir dessa concepção de campo, de Bourdieu, mas intenta-se demarcar o espaço que está sendo avaliado, precisamente a Diocese de Viana, visto que esta noção de campo oferece ideias de que há competências específicas e trunfos ou capitais de que os agentes vão disputando e, em maior ou menor escala, se apropriando. Nesse estudo o campo é o religioso e os agentes, ao incorporarem as propriedades inerentes ao mesmo, teológicas, pastorais, eclesiais, se tornam capazes de atender significativa demanda, diferenciando-se uns dos outros por meio do capital adquirido. Nesse jogo regrado, as normas legítimas estão sempre em disputa impactada pela posição na estrutura e pelo estoque de capitais disponíveis aos agentes em disputa. Trazendo esse esquema interpretativo para a Diocese de Viana, emergem os conflitos em torno da legítima concepção de Igreja e missão religiosa, com os agentes acionando, ora as visões mais tradicionais, ora o Concílio Vaticano II (1962-1965) e a Teologia da Libertação.

\section{DOIS BISPADOS E UMA DIOCESE}

Durante os anos de 1969 a $1985^{8}$, a população brasileira esteve sob um regime ditatorial em que direitos básicos foram usurpados; se expressar ou mostrar ideias divergentes ao regime já era motivo de monitoramento e perseguições, até mesmo para membros da Igreja. Durante o governo Médici esta instituição passou a enfrentar dificuldades em sua relação com o Estado e muitos de seus membros tornaram-se vítimas de atos repressivos, não sendo raros os casos de prisões de sacerdotes e freiras, torturas, assassinatos, cerco a conventos, invasões de templos, vigilância contra bispos (ARNS, 1996).

Sobre este ponto, Azevedo (2012) destaca que as práticas repressivas não constituíam uma resposta contra a instituição Católica, mas contra agentes específicos, engajados na contestação ao Estado ditatorial; isto porque, entre os militares, era habitual a adesão a esta igreja; a ideia era de "limpeza" em todas as áreas e instituições, de modo a eliminar todos os focos de dissenso e contestação. Foram mais atingidos os religiosos seguidores da TL com seus trabalhos majoritariamente realizados na área rural, onde desenvolviam ações de mobilização dos leigos em combate às "injustiças sociais".

\footnotetext{
${ }^{8}$ Período pesquisado pela autora
} 
No Maranhão, trabalhadores rurais viviam uma realidade de desigualdade social, expressa, entre outras formas, pela expropriação de terras, altos níveis de exploração, domínio violento exercido pelas elites rurais e políticas, pobreza e ausência de direitos básicos. Com variações no âmbito do estado, e mesmo da região abrangida pela Diocese de Viana, essa população era constituída por camponeses pequenos proprietários, posseiros, arrendatários e outros tipos, geralmente sob domínio de oligarquias ruralistas e empresários latifundiários, os quais dispunham de poder e liberdade para apropriar-se fraudulentamente de grandes extensões de terras, muitas vezes, apoiados por agentes do Estado. Os conflitos fundiários vão se tornando mais agudos a partir dos anos de 1950, com abertura de estradas e expansão da fronteira agrícola, que fez do Maranhão o maior produtor nacional de arroz. Esta expansão se dava no curso dos rios Itapecuru, Mearim e Pindaré, com fortes impactos em municípios integrantes da Diocese de Viana (LUNA, 1986; ASSELIM, 2009; ALMEIDA, 2001).

Acrescente-se que a concentração fundiária nos anos de 1950, tanto no Brasil como no Maranhão, era tão destacada que em meados desta década, por orientação de Conferência da CONTAG foi instituída no Maranhão a Comissão Estadual de Reforma Agrária ${ }^{9}$, composta por profissionais liberais, como advogados e agrônomos, além de religiosos e estudantes, os quais percorreram várias cidades do estado, principalmente os vales dos Rios Itapecuru e Mearim, difundindo a "campanha nacional" por cinco milhões de assinaturas pela reforma agrária (ALMEIDA, 1981).

À época, o estado era governado por Eugênio Barros (1951- 1956), tendo em sua estrutura de poder, segundo Pinto (1982), um modelo político herdado da República Velha, marcado pelo “clientelismo" e pela presença de "coronéis" ${ }^{10}$ que se configuravam como autoridade máxima de determinado município, expressando-se como o senhor do "seu território" e de amplo conjunto de trabalhadores rurais, os quais Ihe prestavam obediência pelos "ganhos" recebidos, numa relação de trocas de favores, envolvendo

\footnotetext{
${ }^{9}$ Criado durante a Il Conferência Nacional de Trabalhadores Agrícolas realizada em São Paulo em 1954, emergiu da deliberação de uma campanha de assinaturas de trabalhadores rurais que reivindicavam reforma agrária democrática com a entrega dos títulos de propriedade da terra aos que nela trabalham e com a extinção dos latifúndios (ALMEIDA, 1981).

${ }^{10}$ Embora a literatura especializada aponte o coronelismo como fenômeno político, circunscrito ao Brasil nos anos de 1889 e 1930 (LEAL,1997; CARVALHO, 2004), no Maranhão, paradoxalmente, modalidades do mesmo podem ser identificadas entre 1945 e 1965, quando o estado esteve sob política oligárquica liderada por Vitorino Freire, cujos métodos reproduziam aqueles descritos por Leal (COSTA, 2006).
} 
pequenos benefícios e apoio eleitoral nos municípios aos candidatos indicados pelos coronéis e chefe político estadual, senador Vitorino Freire ${ }^{11}$.

Nesse período eram recorrentes os conflitos agrários, desencadeados pela expropriação de terras e exploração de lavradores. No caso de alguns municípios da Diocese de Viana, da Baixada Maranhense, as tensões eram relacionadas aos elevados preços dos aforamentos e devastação das roças pelo gado dos grandes fazendeiros vizinhos. Em face desses conflitos, em 1958, a Associação dos Trabalhadores Agrícolas do Maranhão (ATAM) reforça a organização de pequenos proprietários e foreiros nas áreas de maiores tensões, como o Vale do Itapecuru; as regiões do Mearim e do Pindaré, além de municípios da Baixada, como Viana, Monção, São Bento e Mirinzal (ALMEIDA, 1981), sendo os dois primeiros integrantes da Diocese de Viana.

Na cidade de Viana, que era composta por $86 \%$ de lavradores, grande parte dos conflitos se dava em torno do aforamento, que consiste no pagamento de foro aos proprietários pelo uso da terra e que era a forma de sobrevivência da maioria da população desse município. Essa modalidade de ocupação e uso da terra é descrita por um sindicalista/lavrador da região da seguinte forma:

Os trabalhadores rurais trabalhavam geralmente de meia com os donos de terra ou foro. Então eu sou o trabalhador rural e você é o dono da terra, eu vou aforar sua terra, eu pago, ou eu dou nos produtos depois de apurados, arroz, farinha, feijão. Toda colheita que dava na roça era dividida com o dono da terra. Então, a gente ficava e dava pronto. Não é que eu desse a mandioca ou desse o arroz. Não! Dava tudo pronto, a farinha, o arroz já pronto no saco. Então os trabalhadores eram muito mal tratados, explorados naquela época. Fora os que tinham alguns pedaços de chão de terra, que vinham as pessoas que tinham mais, os grandes donos de terra, e aí encostavam naquele espaço e compravam a preço barato e com isso as pessoas vinham para cidade, para a periferia das cidades. (SINDICALISTA/LAVRADOR)

No fim dos anos 1960, a situação dos lavradores se agrava com as medidas do Estado, como a instituição da Lei de Terras (no 2.979, de 17 de julho de 1969), que autorizou vendas de terras devolutas com preços baixos, sem concorrência pública e sem leilão e a criação da COMARCO (Companhia Maranhense de Colonização), a qual dividiu as terras em áreas de grandes empresas, ocupações mais antigas e área de colonização. Com essas medidas o governo ordenava a ocupação, transferindo grandes áreas para empresários e promovendo a remoção dos habitantes por meio de milícias e da polícia do

\footnotetext{
${ }^{11}$ Recebendo amplo apoio do governo federal, não precisou do cargo de governador para exercer seu domínio, atuando sempre na câmara e senado federal: senador por três mandatos (1947-1955; 1955 a1963;1963 -1971), firmando ao longo desse tempo boas relações com os coronéis e supremacia na política local, elegendo ao governo seus aliados.
} 
Estado, nas chamadas "operações limpeza". Assim despertava interesses de diversas empresas em adquirir essas terras, desencadeando massivas expulsões de trabalhadores rurais dos territórios onde moravam e trabalhavam. Nesse processo, a pequena agricultura foi substituída, no primeiro momento, por pastos e estradas, e já nos anos 1970, pelos chamados grandes projeto, com seus portos e ferrovias (ASSELIN, 2009, BORGES, 2008).

\subsection{Lutas sociais na diocese de Viana}

O município de Viana está situado na microrregião denominada Baixada Maranhense, é composta atualmente por vinte e um municípios ${ }^{12}$. A cidade localiza-se a 219 quilômetros da capital do Maranhão, nela se encontra geograficamente a Diocese de Viana, criada no ano de 1962, sendo desmembrada da Arquidiocese Metropolitana de São Luís durante o arcebispado de Dom José de Medeiros Delgado $^{13}$, conservando-se sufragânea desta Arquidiocese.

O processo de formação da Diocese de Viana ocorreu de forma descontínua, pois após o primeiro pedido de sua criação, datado de 1940, ficou alguns anos sem prosseguir, até ser retomado no fim dos anos de 1950. Os procedimentos para a formação desta Diocese iniciaram-se quando o pároco da Igreja, Manoel Arouche (1906-1958), solicitou ao arcebispo de São Luís, Dom Carlos Campelo de Vasconcellos Motta ${ }^{14}$, a criação da nova Diocese. Este mostrou-se de acordo com a ideia, dada as dificuldades de acesso à casa paroquial de Viana, pois o trajeto de São Luís pra Baixada do Maranhão era bem difícil. As estradas eram quase inacessíveis, sem asfalto, com apenas um caminho de barro, difíceis para viagens de carros pequenos e mesmo de ônibus, que só trafegavam em período de secas; as viagens por água também não facilitavam o acesso à Baixada, pois, além do canal do boqueirão ser arriscado; o que se dispunha como transporte aquático eram lanchas, disponíveis durante três vezes ao mês no trajeto capital- baixada e vice-versa.

\footnotetext{
12 Anajatuba, Arari, Bela Vista do Maranhão, Cajari, Conceição do Lago-Ac̣u, Igarapé do Meio, Matinha, Monção,

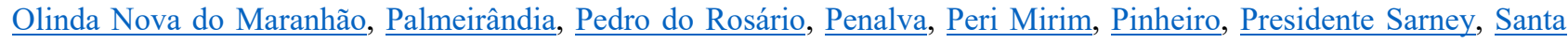
Helena, São Bento, São João Batista, São Vicente Ferrer, Viana e Vitória do Mearim.

${ }^{13}$ Ordenou-se sacerdote em 1929 e doze anos depois foi eleito bispo de Caicó, no Rio Grande do Norte, pelo papa Pio XII, onde exerceu as funções de prelado até Janeiro de 1952. De Caicó, foi transferido para o Maranhão e tomou posse na Arquidiocese de São Luís em fevereiro de 1952. Em São Luís, permaneceu até maio de 1963 quando então foi transferido para Fortaleza e na capital cearense exerceu a sua pastoral como arcebispo até Abril de 1973, momento de sua renúncia ao governo episcopal do Ceará. (PORTO, 2007, p.11).
}

\footnotetext{
${ }^{14}$ Foi o vigésimo quarto bispo do Maranhão e o segundo arcebispo da arquidiocese de São Luís (1935 a 1944).
} 
A construção da Diocese de Viana está intrinsecamente relacionada à atuação do MEB neste município, Rapôso (1982) sustenta que entre os municípios do Maranhão, Viana juntamente com PindaréMirim, foram as localidades onde o MEB operou de forma mais sistemática. Havia, na cidade de Viana, uma equipe vinculada à Igreja Católica chamada Auxiliares Femininas Internacionais (AFIs), a qual atuava no campo social deste município, oferecendo suporte assistencialista à população local.

As AFIs foram criadas em 1962, quando o bispo auxiliar de São Luís, Dom Fragoso, foi ao Canadá e realizou um convênio com a Igreja Católica Canadense para a instalação de uma casa missionária leiga em Viana, a qual, após instalada, passou a contar com uma médica italiana, uma enfermeira belga e uma assistente social alemã; tais ações estreitavam o vínculo do arcebispo de São Luís Dom Delgado com os religiosos do município e com a Santa Sé.

No Maranhão, o MEB foi criado sob a responsabilidade do arcebispo de São Luís, Dom Delgado. Desenvolvendo experiências de ações e reflexões, este movimento realizava assembleias que, além de aludirem às questões de técnicas agrícolas, saúde e educação, promoviam organização de sindicatos e discutiam as estruturas sociais e as possibilidades de transformações através do voto.

Entre os anos 1969 e 1985, a Diocese de Viana esteve sob o comando de dois bispos: Dom Hélio Campos (1969-1975) e Dom Adalberto da Silva (1975-1995), protagonistas de situações conflitivas, tanto no interior como no exterior da igreja. Em relação ao bispado de Dom Hélio, o que primeiro chama atenção é a sua própria indicação, dado que o momento era de endurecimento político (pós Al-5), e este bispo vinha de uma experiência religiosa politizada, com moradores de periferia, no Ceará. Na ausência de explicações conclusivas para essa situação paradoxal, levanta-se como hipóteses plausíveis que: a ditadura militar no Maranhão não era percebida naquele contexto como tão severa, dado o não registro de conflitos diretos com movimentos contestatórios tradicionalmente atuantes no estado; que as relações entre Igreja e Estado no Maranhão não se apresentavam tão conflitivas; ou ainda, que a vinda deste religioso para Viana tenha se dado por motivações pessoais.

Dom Hélio Campos, nasceu no Ceará, em 24 de Julho de 1912, na cidade de Quixeramobim, recebeu sua ordenação em 05 de Agosto de 1937 na cidade de Fortaleza. Foi Capelão do Instituto Beneficente São José, em 1958 assumiu a Paróquia Nossa Senhora das Graças em Pirambu, onde fundou o Centro Social Paroquial Lar de Todos; era conhecido como pertencente ao chamado setor progressista da Igreja Católica e com essa linha de pensamento ele praticou diversas ações voltadas a causas sociais. Ademais, Dom Hélio era seguidor da espiritualidade do beato francês Charles de Foucauld (1858-1916), militar que se converteu ao catolicismo se tornando monge e adotando uma vida de simplicidade e missão pela África (padre 01; padre 02 em entrevista à autora). 
em Viana no estado do Maranhão, as atividades do bispo Dom Hélio Campos (1969- 1975) passam a chamar atenção daqueles que controlavam os indivíduos considerados "perigosos" ao governo. Seguidor da Teologia da Libertação, Dom Hélio Campos acreditava que o papel de um cristão era oferecer instrumentos com os quais os oprimidos pudessem ter força para se "libertar". Ao chegar em Viana, o bispo Dom Hélio Campos tomou logo a iniciativa de convocar um seminário para conhecer a realidade da população da cidade, como se verifica no relato do entrevistado, o qual começou a trabalhar nas CEB's e em seguida se inseriu no sindicato de São João Batista a partir das falas motivadoras deste bispo

Eu comecei exatamente por esse seminário que a gente foi em Viana. A partir daí que eu comecei nas CEB's. Então, Dom Hélio colocava pra gente, para os leigos, que a gente tinha um papel muito importante dentro da igreja, dentro das comunidades, que era essa questão de levar essa discussão de organização, essa discussão como se faz igreja, e que não é só dentro das paredes. Mas a igreja viva, a igreja atuante. (LAVRADOR/SINDICALISTA)

Observa-se que desde seu primeiro seminário Dom Hélio conseguira despertar neste indivíduo pertencente à Diocese o desejo de se engajar em atividades de lutas por transformações na sociedade, destacando-se a participação sindical. Nota-se no exemplo citado que o ambiente de mobilização, que se expandia em Viana, levava pastorais sociais e sindicatos a ganharem mais fôlego, com muitos leigos se engajando nessas atividades desde o primeiro contato com o bispo. A experiência relatada pelo sindicalista apresenta a figura deste religioso como um elemento decisivo em sua experiência de engajamento em movimentos políticos.

No ano de 1970, Dom Hélio Campos convida o padre Eider Furtado para retornar a Viana. Este aceita e passa a trabalhar como Vigário Episcopal ${ }^{15}$ (ou Vigário Geral, administrador da Diocese). Juntos retomam as atividades com as CEB's em um tempo em que esse tipo de ativismo, mesmo de cunho religioso, era mal visto pelo governo e seus órgãos de seguranças. Desse modo, foram monitorados pelo SNI, juntamente com demais padres da Diocese, conforme se pode ver nos seguintes registros da DOPS MA.

\footnotetext{
${ }^{15}$ Ressalta-se que o vigário assume um serviço instável podendo ser transferido a qualquer momento a critério do bispo, possui a mesma incumbência do paróco, tomar conta de determinada paróquia, estando circunscrito no auxílio ao pároco, este responde pela Diocese juridicamente, administrativamente e pastoralmente.
} 
Figura 1- Ficha do Padre Eider Furtado na DOPS-MA (Frente)

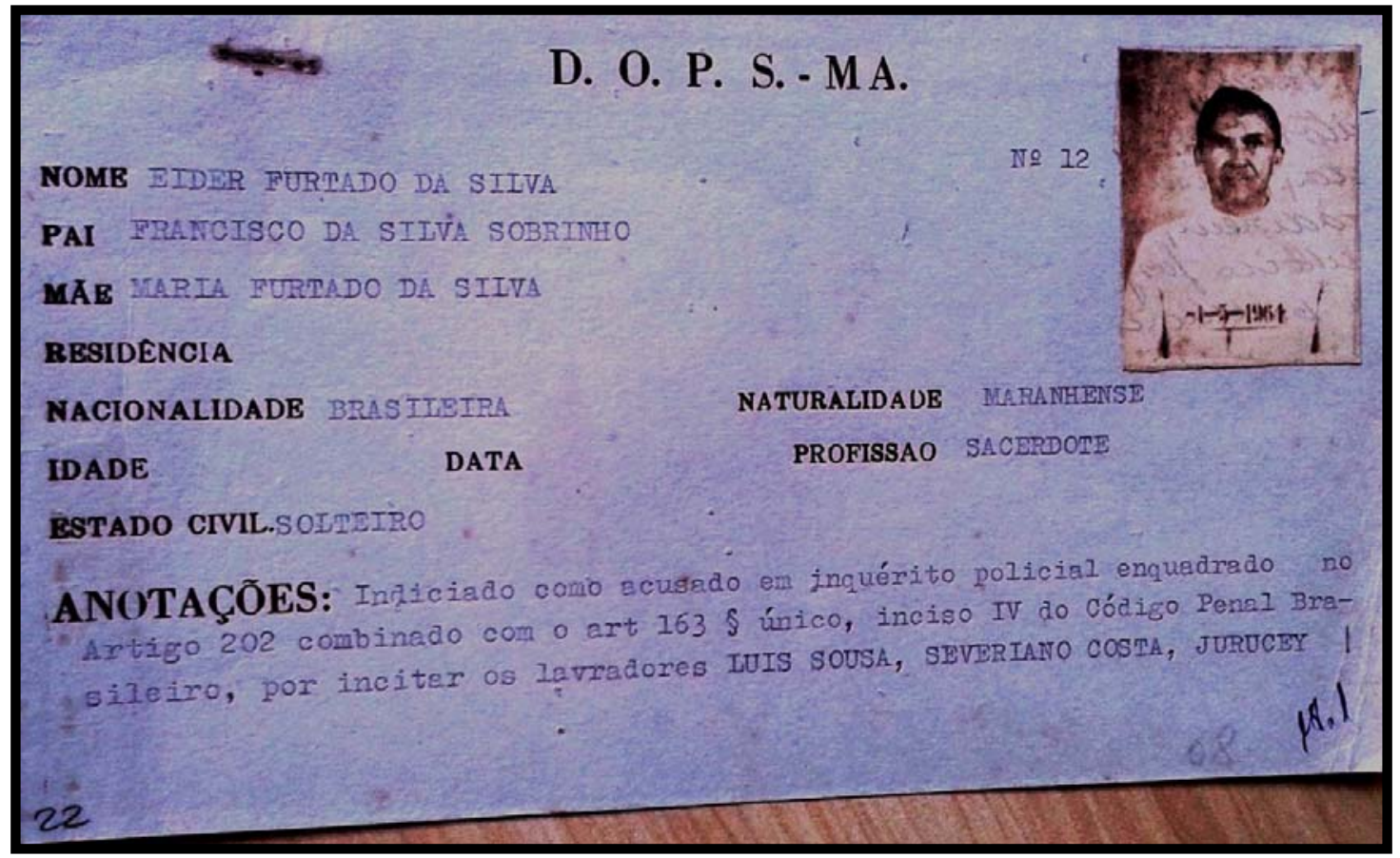

Fonte: DOPS-MA. Série Subversão. Dossiê 29.

Figura 2- Ficha do Padre Eider Furtado na DOPS-MA (Costa)

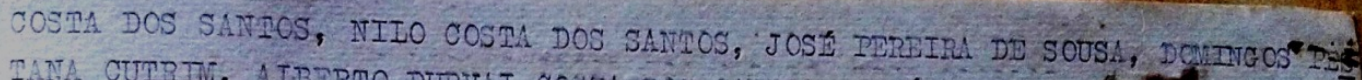

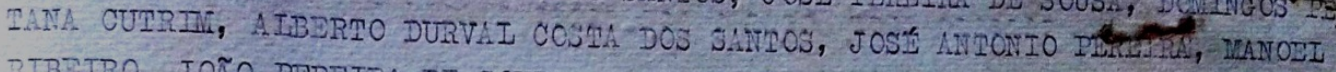
RIBEIRO, JORO PEREIRA DE SOUZA, RAIMUIDO ITONATO PINHSIRO E ROSEITAL DOS SAN TOS a invadirem, cortando arane dos Srs. JOSS MIMDIS PINHPIRO e ANTONIO PIMTIIRO GLSPAR. O reverendo em aprego chegou a invadir a Delegacie do Nlunici pio de Viana, deste Istado às 20 horas do dia $23 / 12 / 72$ para ficăr dentro de un dos xadreses dizendo querer ser preso, em decorrência da detenção por parte do Delegado local dos lavradores que invadiram referida propriedade.A autoridade citada abriu as portas da capeia e testemunhou o fato para que 0 padre não fosse mais tardé alardear que tinha sido preso, vez que esse era s'eu objetivo para colocar os Orgãos de Segurança em dificuldade, prática já - muito conhecida do clero "progressista". No curso do inquérito citado o clé rijo, recusou-se a prestar declareções. I de bom aviso citar que o epigrafa do recebe ordem direta do Bispo D. PRAMTCISCO HílIO CAMPOS, já fichado peloś Orgãos de Seguranşa, recentemente tendo visitado no Rio de Jeneiro o subrey sivo ILANOEI: CONCEIÇNOO SAMTOS: preso por esta DOPS, neste Estado quando prega va o regime comunista aos rurículas deste Istado.

Fonte: DOPS-MA. Série Subversão. Dossiê 29. 
Figura 3- Dom Hélio Campos na DOPS-MA

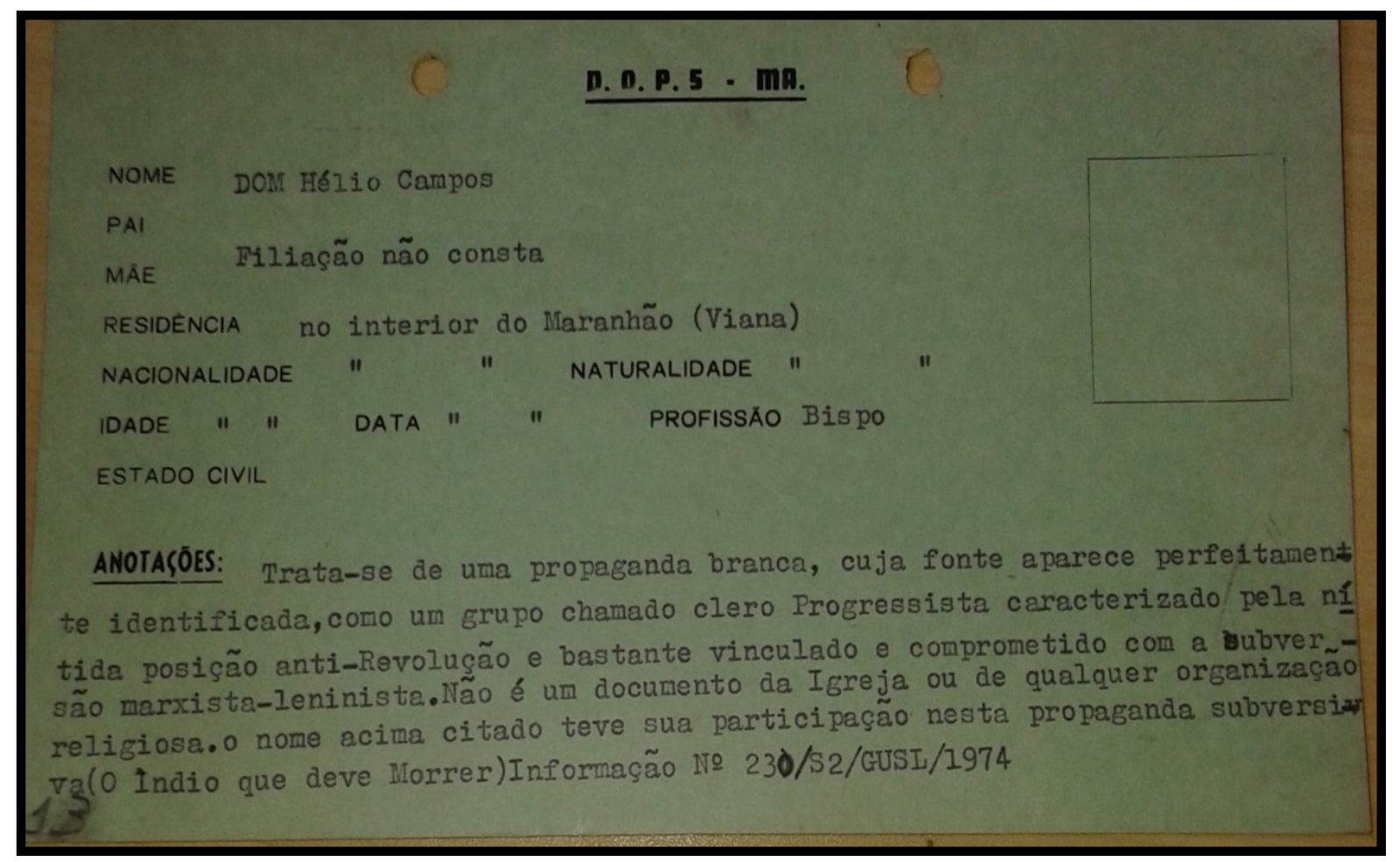

Fonte: DOPS-MA. Série Entidades Religiosas. Dossiê 12.

A chegada de Dom Hélio em Viana desencadeou mudanças em diversos âmbitos, uma vez que não se limitou a questões religiosas, como normas sacerdotais, tradições da igreja e sacramentos; voltouse, principalmente, à questão social, na perspectiva de levar "conscientização política" para os trabalhadores e leigos, buscando mostrar-Ihes que todos tinham condições de ser sujeito de suas próprias transformações. Observa-se nestas visões traços que são representativos de todos os campos: o esforço de manutenção das posições daqueles que são dominantes ou possuem trunfos, no caso, a ideia do religioso levar a consciência para o trabalhador, ao mesmo tempo que expressa uma disposição de compartilhamento e isonomia entre os agentes, explicita as diferenciações e hierarquias internas, as posições dominantes e dominados, os que possuem e distribuem a "conscientização" e os que a recebem.

$\mathrm{Na}$ declaração do entrevistado verifica-se a preocupação do bispo na transformação de pastoral de "tutela" para uma que seguia a Teologia da Libertação, a qual se fundamentava na práxis histórica do homem, com capacidade de transformar a sua realidade, orientava o indivíduo a assumir o papel de ser o "sujeito da transformação na luta pelos seus direitos".

Fui muito ligado com a pastoral da juventude em Viana, tivemos um bispo Dom Francisco Hélio Campos que chegou modificando toda a pastoral antiga dos religiosos italianos que 
tinham lá. Ele [Dom Hélio] chegou modificando, e isso criou um grande alvoroço. [Dom Hélio] era ligados a Teologia da Libertação tanto o bispo como o padre Eider. (LEIGO 01)

As fichas de Dom Hélio e do Padre Eider Furtado possibilitam perceber que as mudanças nas atividades pastorais, ocasionaram tensões não somente no interior da igreja, mas também na relação dos religiosos com o Estado ditador da época. A ficha do padre Eider (Figura 1) mostra que este foi indiciado como acusado em inquérito policial e enquadrado nos artigos 202 e 163 do código penal, que embasaram a acusação do sacerdote por invasão ou ocupação de estabelecimento industrial, comercial ou agrícola, conforme diz o art. 2002. A denúncia se completa com o art. 163 que se refere aos crimes de calúnia. A ficha (Figura 2) também informa sobre lavradores que teriam sido "incitados" pelo religioso a invadir e cortar arames de terras particulares. Menciona que o sacerdote chegou a invadir a delegacia para ficar dentro de uma das celas, oferecendo-se também para ser preso em decorrência da detenção dos lavradores. O Delegado local abriu as portas da cadeia e testemunhou o fato para que o padre não fosse alardear que tinha sido preso, pois, segundo esses órgãos de segurança, o seu objetivo do padre Eider seria coloca-los em dificuldade. Na ficha consta que essa prática já era muito conhecida do clero progressista e que o padre havia se recusado a declarar que recebera ordem direta do bispo Dom Hélio Campos, o qual também já era fichado pelos órgãos de segurança e recentemente havia visitado no Rio de Janeiro Manoel da Conceição (líder sindical da cidade de Pindaré- Mirim, pertencente a diocese de Viana) que "pregava" o regime comunista aos rurícolas no Maranhão.

No depoimento seguinte pode-se observar o acolhimento da nova pastoral pelo padre estrangeiro, informando a formação política que ofereciam as comunidades:

O objetivo da formação era ajudar as pessoas a lerem criticamente a realidade dentro da qual viviam. O histórico, as referências à história do passado serviam para colocar as pessoas na condição de ler criticamente o presente. Se fazia essa formação parte no interior, parte em algum povoado grande do interior e parte se fazia diretamente no Bom Jardim. Então, eu convidava Dom Hélio e também padre Eider porque eles tinham conhecimento melhor do que eu do povo, das realidades. Se comunicavam, sobretudo, padre Eider que era nativo, se comunicava de uma forma mais compreensiva para todos (PADRE 01).

No bispado de Dom Hélio, as interações entre os sacerdotes estrangeiros e locais, se formaram em meio a processos de adaptações, visto que as atividades dos primeiros inicialmente focadas no assistencialismo (estimulada pelo bispo anterior a Dom Hélio) foram gradativamente incorporando as orientações do novo bispado, guiado pela Teologia da Libertação e consequentemente, por uma visão 
religiosa mais politizada. Nesse processo também vão se alterando as relações entre agentes religiosos e agentes do Estado.

Por força de suas posições na estrutura do campo, a objetivação das concepções e práticas do padre Eider e do bispo Dom Hélio, produziam efeitos dos mais diversos tipos e contraditórios, que iam do agravamento das medidas de vigilância e controle pelo Estado policial, até o fortalecimento das organizações populares, cujos participantes se viam encorajadas pelo apoio recebido de autoridades da Igreja. Assim, o reconhecimento de ambos os religiosos nesse papel se desdobrava em trunfos ou dificuldades, a depender de quem avalia e dos contextos sociais em que se localizam, podendo, inclusive haver ressignificações nesse processo, ou seja, o que em um tempo e espaço se configurou como positivo, em outro pode ser tomado como negativo, o que confirma o caráter dinâmico e simbólico do campo (BOURDIEU, 2008), ou seja, o que era considerado trunfo no campo religioso, não era no campo político.

Dom Hélio faleceu em Janeiro de 1975, de câncer no estômago, porém em Dezembro de 1974 participara da celebração da missa de Natal na Paróquia Nossa Senhora da Conceição, na Diocese de Viana. O bispo teve todo seu sermão gravado e copiado pelos órgãos de segurança do Maranhão, no registro consta suas palavras de incentivo e de despedidas, entre elas há um destaque com letras garrafais no momento da homilia em que o bispo faz referências as palavras de um lavrador, o qual disse: "A voz do nosso Bispo pode ter calado, pode se calar, mas a nossa voz não se calará mias, nós descobrimos o Cristo, nós descobrimos o libertador". O destaque que é dado pela Polícia Federal, desta alusão que o Bispo faz a fala de um lavrador, mostra que mesmo com uma possível morte, a Diocese havia razões para a continuidade de um acirrado monitoramento.

Padre Eider, após o falecimento de Dom Hélio foi eleito Vigário pelos padres para que administrasse a Diocese até a chegada do novo bispo. Contudo, essa votação foi ignorada pelo Núncio Apostólico, que indicou o arcebispo da capital, Dom Mota e Albuquerque (1964-1984), como administrador da Diocese. Essa medida ocasionou revolta entre os religiosos que, como resposta, encaminharam uma carta ao presidente da CNBB, ao Papa Paulo VI, ao Núncio Apostólico, aos cristãos, aos Bispos do Brasil e ao arcebispo de São Luís, todas elas com teor de denúncia contra "abuso de poder" e "desrespeito à autonomia da Diocese pelo Núncio Dom Carmine Rocco".

Enquanto, no Brasil, o clima em meados dos anos 1970, era de gradativa abertura política, no interior do Maranhão, especialmente na cidade de Viana, o clima era outro. Conforme a obra O Evangelho Segundo Viana, o amigo do Frei om Adalberto e do Núncio Apostólico, General do Exército Brasileiro da 10으 RM, Florimar Campelo natural de Viana, e contrário aos trabalhos pastorais "subversivos" realizados por Dom Hélio Campos, o que o levou a articular-se com a Nunciatura Apostólica para nomear um bispo que 
apoiasse o regime. Com este propósito, solicita ao Núncio Apostólico, Dom Carmine Rocco, que indicasse seu amigo, Frei Adalberto Paulo da Silva, o que demonstra e reforça, na cidade de Viana poder bastante influente de um militar.

Ao assumir o posto episcopal da Diocese de Viana, Dom Adalberto da Silva, passa a proibir as atividades desenvolvidas pelos religiosos com os camponeses. Nova configuração foi se formando e as ações dos padres passaram a ser tomadas de acordo com a atuação de poder de Dom Adalberto; lavradores, sindicalistas e religiosos passaram a não utilizar mais o salão paroquial da igreja em Viana. Essa postura se manteve ao longo do seu bispado, e em depoimentos, é possível verificar sua visão de religião segundo a qual, é estreitamente relacionada às questões de o bispo expõe as informações que lhe foram passadas, sendo também sua visão de pastoral, correspondendo ao mesmo conteúdo que consta no informe da DOPS/MA (Figura 4). Segundo ele, a Nunciatura Ihe orientou a transmitir a "verdadeira pastoral", menciona sobre as condições encontradas por ele na Diocese

Estive em Viana em um período difícil, porque socialmente era o período da ditadura. Em termos de Igreja Católica, de religião, era um período muito difícil também, por causa da infiltração das ideias socialistas e marxistas na igreja, e em toda parte do mundo [...] a Nunciatura mandou-me pra lá como novo Bispo pra eu implantar a verdadeira ortodoxia pastoral lá na região [...] as CEB's tinham orientação da igreja, e não era pra nenhum padre se desviar, nem desviar as comunidades para outras totalidades de CEB's [...] Então, eu levava para que eles fossem assim, sem receber orientações marxistas (BISPO).

Eu encontrei uma situação em que as preocupações dos padres, das irmãs, das freiras da pastoral no interior, das paróquias eram a seguinte: deixavam a sede da paróquia, as vezes na festa do padroeiro, em Viana. Nas festas do padroeiro da própria paróquia! Não tinha nenhuma preocupação com a sede [com a paróquia]. Quem administrava a padroeira [...] era só cuidar, por exemplo, de orientar os lavradores, levantar os que moravam ali, os pobres, contra os que tinham certas possiblidades de bens, ricos e era uma situação preocupada mais com a situação social orientada pela ideologia marxista do que o trabalho de orientação de uma sociologia evangélica, de acordo com o ensinamento de Jesus Cristo. Imediatista, orientada para a desobriga das classes inferiores no lugar da paróquia, em vez de cuidar das coisas da religião, pregação, confissão, celebração, batismo e outros sacramentos, iam cuidar era da conferência dos lavradores, incita-los contra os proprietários [proprietários de terras], isso era uma coisa bastante conflituosa (BISPO). 
Figura 4 - Informe sobre o clero progressista do Maranhão

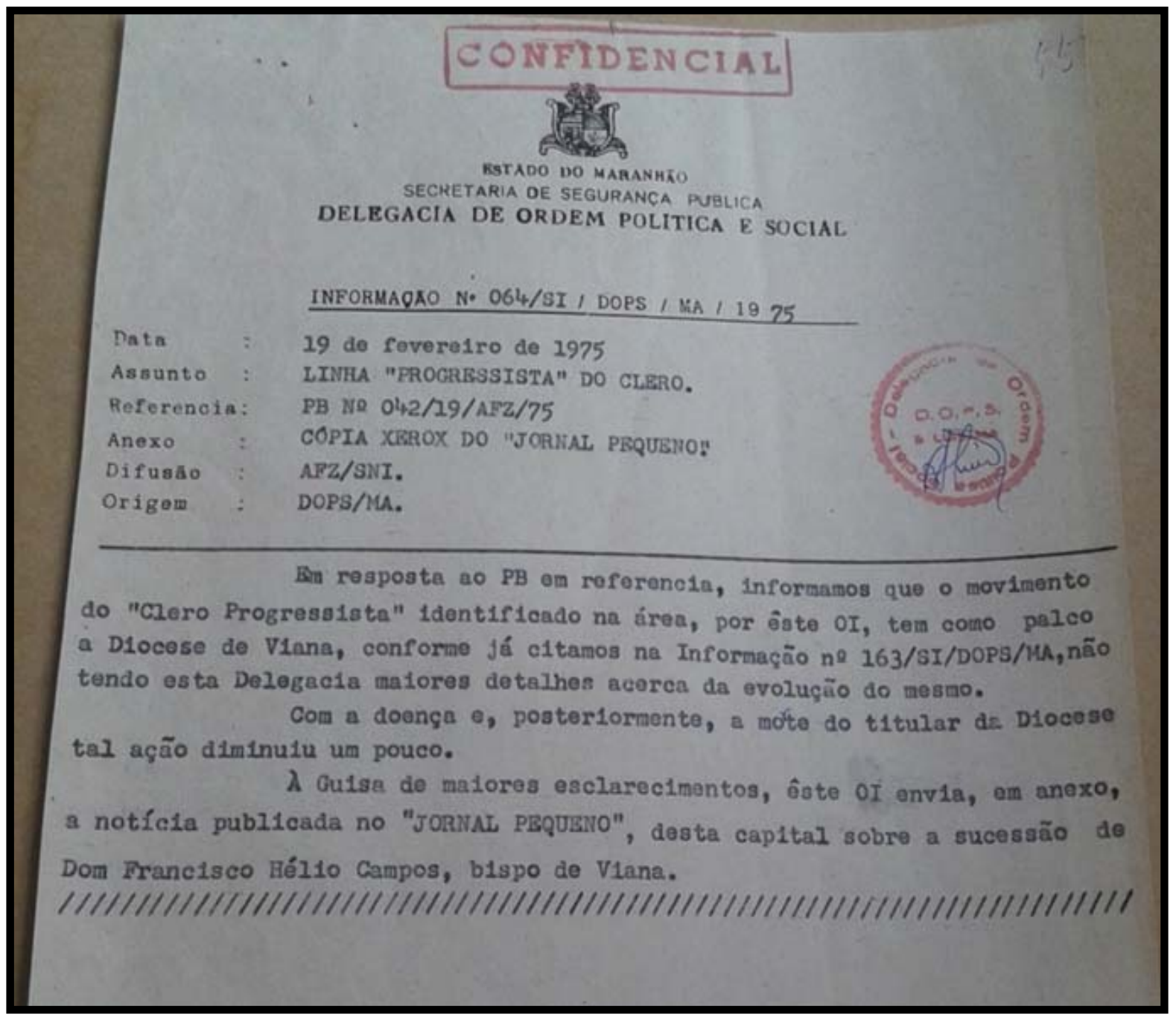

Fonte: DOPS-MA. Série Entidades Religiosas. Dossiê 12.

Este documento da DOPS/MA datado no dia 19 de Fevereiro de 1975, quase um mês após a morte de Dom Hélio Campos (23/01/1975) informando sobre a centralidade do clero progressista no estado do Maranhão ser em Viana. O documento alude a um processo sistemático de acompanhamento ao que denominam clero progressista que tem como palco a cidade de Viana. Apesar de se declarar "sem maiores detalhes", neste único documento há referencias a um pedido de busca (n 042), 02 informações (n 064 e 163), além de acompanhamento da situação pela imprensa. Tudo isso confirma o elevado grau de monitoramento e ingerência dos órgãos de segurança sobre organizações da sociedade civil, incluindo aquelas de natureza privada, como a igreja. 
As práticas do bispo Dom Adaberto foram revestidas de autoritarismo e de indiferença as condições das disparidades sociais na Diocese de Viana, posto que, além não oferecer espaços aos encontros de reuniões aos camponeses, coagindo religiosos e leigos, dava como exemplo, grandes punições a eles, como expulsões aos que podia expulsar e excomunhão ao sacerdote nativo, padre Eider, que não recuou diante o autoritarismo do bispo. Utilizava-se assim de todas as estratégias do jogo, que seu posto Ihe permitia. Abaixo pode-se verificar o relato do lavrador informando a proibição de seminários organizados aos lavradores, atividade essa habitual no período de Dom Hélio, em declaração a autora o Bispo contrapõe os registros sobre a expulsão de religiosos, relata que não aceitavam a pastoral ortodoxa, a qual defende como sendo a verdadeira pastoral da Igreja. As interdições de dom Adalberto às mobilizações políticas com os lavradores, muito comuns no bispado de dom Hélio, assim como as perseguições aos religiosos que não se submetessem à "pastoral ortoxa" imposta pelo novo bispo, são narradas por um sindicalista da seguinte maneira

Nós não podíamos ir a seminários (Reuniões em que se discutiam a situação dos lavradores), mas o que aconteceu de imediato foi que ele expulsou os padres com as freiras logo, foi em cada um da gente que tinha feito esse tipo de trabalho (mobilizações de camponeses) e proibiu atuar, e proibiu falar de qualquer coisa de igreja com ele. (SINDICALISTA/LAVRADOR)

O Bispo Dom Adalberto por assumir uma posição hierárquica privilegiada em relação aos demais religiosos, passou a ditar as regras do que seria possível ou não na Diocese que ocupava. Para Elias (2000) o poder não é uma substância, mas um atributo das relações humanas, que se mantêm em um equilíbrio instável de forças, em continuidade a esta mesma concepção.

Neste sentido verifica-se a diferentes formas de poder nas relações existentes na diocese de Viana, se antes o poder era harmônico entre os religiosos, em que estes usufruíam em prol da população camponesa, pelos seus direitos humanos, confrontando-se com a elite de latifundiários, de políticos e com os militares; com a chegada de Dom Adalberto a relação de poder no campo religioso passa de uma consonância a uma inconsonância, uma vez que os religiosos não reconheceram o terceiro bispo como pertencente ao seu grupo religioso, dado que não seguiram seu modelo pastoreio, já que possuíam discrepâncias na forma de compreender Igreja e, por conseguinte, pastoral, o que levou a expulsão dos religiosos estrangeiros.

A perspectiva elisiana considera as configurações como um curso de ações variáveis no jogo social, e nesse curso o poder também é instável, em que há tensões e desequilíbrios entre os indivíduos interligados, nesse curso há presença de conflitos e cooperações. As lutas pelo equilíbrio de poder podem 
ser manifestadas tanto por pressões tácitas, quanto por pressões abertas (ELIAS, 2000), o contexto da ditadura possibilitou as duas formas pela disputa de poder, haja vista que havia uma configuração específica formada por presença de violências físicas, como pressões psicológicas, o que formou conflitos entre religiosos e governo no período de Dom Hélio. Com a chegada de Dom Adalberto há composição de novas configurações no campo religioso, o qual não é mais harmônico, as relações passam de cooperação a conflitos.

A diocese de Viana é percebida como uma instituição em um constante processo de construção em que agentes específicos do campo religioso, que possui leis e funcionamento próprio, se apresentaram em uma constante luta pela legitimidade de fazer pastoral. O bispo Dom Hélio em uma relação de interdependência com os demais agentes do campo ao incorporar as estruturas sociais acionando seus conhecimentos sobre o aggiornamento, da mesma forma o padre Eider, investiram no campo e contribuíram para a reprodução do jogo, com adaptações e cooperações dado que a "luta tende continuamente a produzir e a reproduzir o jogo e tudo o mais que está em jogo, reproduzindo naqueles que se encontram diretamente envolvidos nele" (Bourdieu, 2008, p.45). Assim, as relações de força são redefinidas com a entrada de Dom Aldaberto que aciona sua rede de relações para jogar no campo religioso, porém as normas que já redefiniam anteriormente o jogo faz com que ele não tenha o reconheciimento dos religiosos da Diocese. $\mathrm{O}$ que o leva a buscar uma redefinição expulsando e recrutando novos seminaristas que pudessem compartilhar sua visão, na ótica de Bourdieu as lutas simbólicas pelo poder de produzir e impor visão de mundo são constitutivis do campo simbólico (Bourdieu, 2011).

Neste campo de forças o padre Eider não cessou suas denúncias sobre as práticas de Dom Adalberto em que o mesmo, usando de estratagemas conseguiu o afastar de suas funções, em resposta, padre Eider o colocou na justiça do trabalho, o que lhe resultou de uma excomunhão. Esses cnflitos foram acompanhados e registrados pela imprensa, como pode-se observar nas figuras seguintes abaixo. 
Figura 5- Denúncia ao Bispo Dom Adalberto

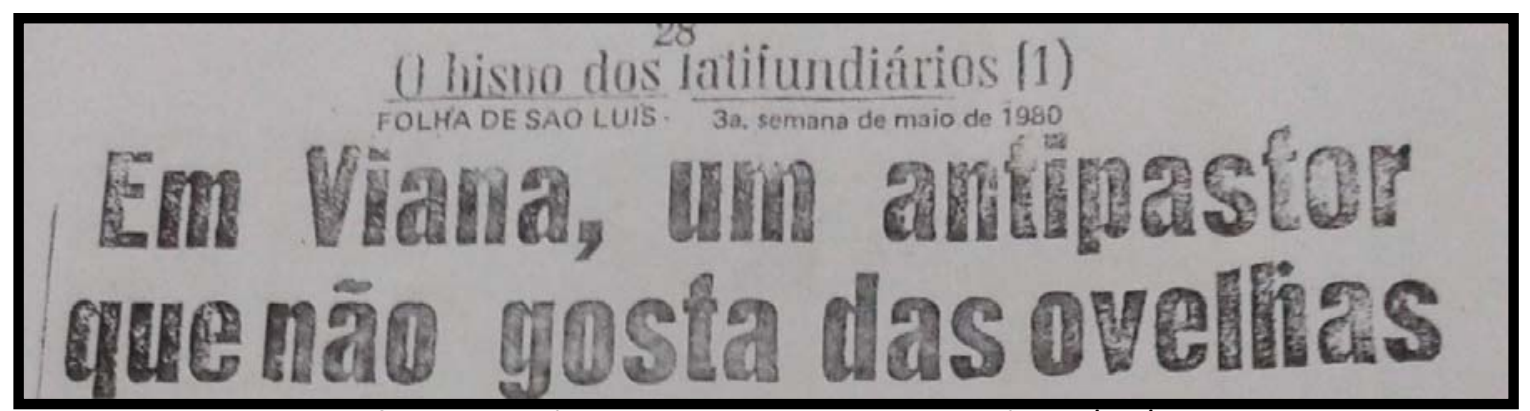

Fonte: CPT - Caixa: Conflitos Eclesiásticos Jornal Folha de São Luís: 03/05/1980

Figura 6 - Bispo Excomunga Padre

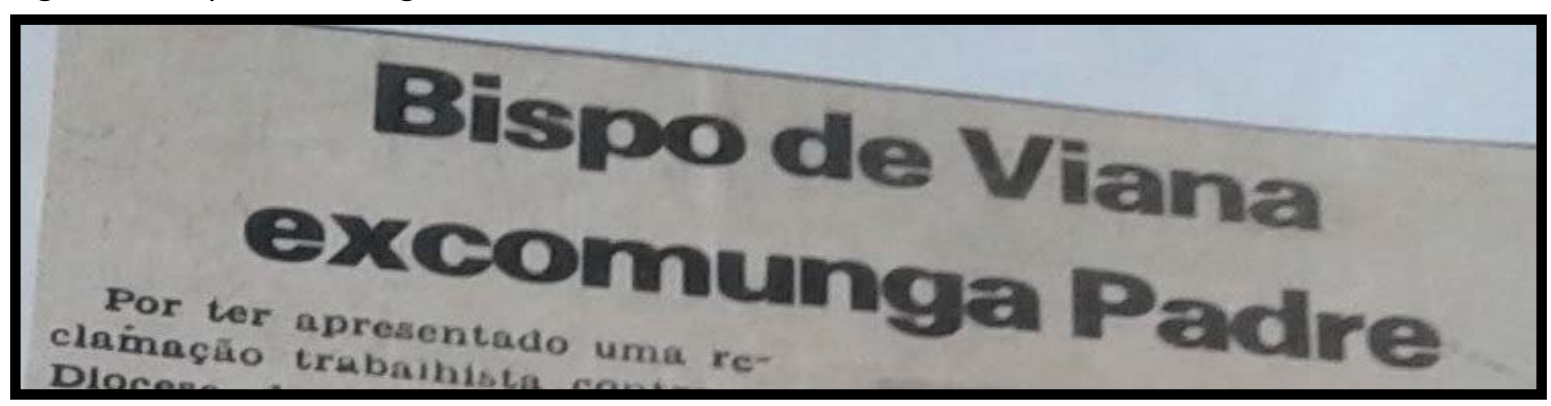

Fonte: DOPS-MA. Série Entidades Religiosas. Dossiê 10. Jornal O Imparcial. 02/05/ 1982

Ressalta-se que as configurações são criadas pelos jogadores, através de suas relações com o os outros, existindo a interdependência entre eles. Nesse sentido, a atuação dos demais religiosos estava sob as ações dos bispos, os quais apresentavam seu poder de decisão de acordo com o seu lugar de origem e de suas crenças.

As concepções e práticas políticas e religiosas de cada um desses bispos, assim como as do padre Eider, podem ser entendidas em sentido weberiano, segundo o qual, estas ações foram construídas em um tempo e espaço específico, de múltiplas teias de significado. Cada um dos bispos jogou com o que estava em jogo, segundo suas concepções. Para Dom Adalberto a preocupação central era acabar com trabalhos pastorais considerados "tortuosos" desenvolvidos pelo seu antecessor, Dom Hélio Campos, no caso, as, ações políticas e reivindicativas dos grupos de lavradores. Avesso aos elementos da Teologia da Libertação, Dom Adalberto, considerava que a prioridade dos membros da igreja a prática da obediência, dos sacramentos e rituais religiosos. Sobre estas diferentes visões de Igreja, fé e práticas religiosas, os entrevistados relatam 
Só sei que eu tinha que ajeitar as tortuosidades que eles tinham na pastoral, e pra começar essa era a ideia, essa é a orientação da Igreja, vindo da nunciatura apostólica lá de Brasilia, em vista de melhorar a situação de igreja na própria região de Viana na Baixada Maranhense. (BISPO)

O Dom Adalberto chamou os seus confrades capuchinos para fazer uma pregação pra nós, e passamos três dias ouvindo pregações e como dizia, obedecer, obedecer, obedecer, obedecer, obedecer sempre ao bispo e tudo aquilo que ele quisesse mandar fazer, nós deveríamos obedecer isso, isso e aquilo. E inclusive vieram também duas coirmãs que eram superioras dessa congregação, a madre geral e a secretária que participaram também do encontro, e viram que muita coisa q não tinha nada a ver do que talvez ele queria falar mas era um modo de dizer vocês não estão obedecendo, vocês não estão com a igreja, vocês não estão fazendo aquilo que o bispo quer (FREIRA)

A persistência na continuidade da pastoral de Dom Hélio, de seguir as orientações do bispo anterior durante o bispado de Dom Adalberto acarretou consequências dentro e fora da Igreja no âmbito externo, a retirada dessa mediação institucional forte e prestigiada, deixou os camponeses em condições muito vulneráveis, expostos A perseguições, pressões, torturas, como também morte de camponês. Pois já não possuíam aquele mediador, com "capacidade de interagir em diferentes domínios sociais e de lidar com vários códigos e valores" (Ros, 2008, p. 101), esta situação agravou situações de conflitos que antes, no período de Dom Hélio não eram habituais.

Chama atenção o fato de que, no período mais difícil da repressão política no país, o bispado de Viana, conduzido por dom Hélio Campos alinhou-se a opção preferencial pelos pobres, indicada pelo Vaticano II (1962-1965), Conferência de Medellín (1968) e reforçada na Conferência de Puebla (1979) e no período da transição, onde as pressões ditatoriais já se faziam mais frouxas, o bispado da cidade, cujo grau de violências locais não se atenuara, Dom Adalberto declara verdadeira campanha contra o que se chamaria de Catolicismo Popular, ou seja, uma igreja mais sensível e engajada com os ideais de justiça social priorizando um fazer religioso mais endógeno voltado aos sacramentos e focado na salvação da alma. Assim Dom Adalberto protegia-se dos riscos associados ao catolicismo popular, reputando aos religiosos palavras depreciativas, o que era recorrente no regime, tais práticas levaram muitos religiosos e leigos a serem denominados comunistas, torturados, e por vezes mortos (SERBIN, 2001).

Houve no período da ditadura uma abertura às práticas de padres ativistas, o contexto contribuíra para suas posições progressistas, dado que as torturas, desaparecimentos e mortes se agravavam. Na sociedade em Viana a realidade era de disparidade social, a luta por sobrevivência e direitos mínimos, como moradia, fazia parte da vida da maioria da população. Assim, os movimentos da Ação 
Católica e as CEB's tiveram uma forte atuação na cidade, e, se em todo Brasil era recorrente maiores engajamentos de padres e freiras, em Viana houve também o apoio de um bispo, contribuindo para o crescimento de movimentos populares na Diocese. O período ditatorial foi o momento em que mais cresceu movimentos leigos no país (MAINWARING, 2004). Na Diocese de Viana semelhante ao restante do país, movimentos leigos com apoio dos religiosos buscavam a transformação de suas realidades, combatendo as injustiças sociais, fundamentados em um ativismo progressista.

Com a morte de Dom Hélio as mobilizações declinaram, as organizações de ações coletivas, associações e sindicatos perderam formadores políticos, uma vez que freiras, religiosos e leigos estrangeiros foram sendo proibidos de realizarem atividades que tinha cunha de"Igreja popular". Assim os movimentos ficaram mais frágeis, ademais os leigos também eram ameaçados pelo bispo, sendo pressionados a não continuarem as mobilizações.

\section{CONSIDERAÇÕES FINAIS}

As atuações dos religiosos, em especial, do bispo Dom Hélio, podem explicar o episcopado posterior, que é entendido a partir de suas ações, uma vez que suas tomadas de posição culminaram na interferência por um agente militar, General Campelo, da 10a RM, da nomeação do terceiro bispado da Diocese de Viana. Em que pese à existência de lados de amizade desse general com Dom Adalberto e o Núncio Apostólico, essa atitude se configura como uma intervenção do poder militar sobre a Igreja Católica.

Ressalta-se que o entendimento relacional, um explicando outro, com interpenetrações de diferentes configurações com outras, contribui para a compreensão das atuações dos bispos da Diocese de Viana. A forma de Dom Hélio atuar no campo religioso respondia as soluções às dificuldades sociais e econômicas da população, como também dizia respeito à forma que o Estado lidava com agentes considerados "desordeiros".

Dom Adalberto, que chegara a Diocese como o propósito de fazer uma "limpeza", passando a desenvolver estratégias para tal, se assegurou pelas estruturas sociais que se inseria, uma vez que não obteve reconhecimento pelos religiosos que seguiam as orientações do bispo anterior. Outro elemento de suporte ao êxito de Dom Adalberto da Silva é sua rede de relações sociais com agentes de outros campos, em que o contexto ditatorial contribuiu para que estas relações pessoais tivessem peso no campo religioso, mantendo-se com suas estratégias. Usou de estratégias como incluir novos agentes no jogo, afastando religiosos que não eram seus aliados, ou seja, abriu novos Seminários para ordenação de padres, e 
gradativamente, por meio de suas relações pessoais, já que era prezado por outras autoridades religiosas e do governo, conseguiu paralisar as atividades as quais não compartilhava, cumprindo assim, o propósito de "limpeza”.

Chama atenção que na diocese de Viana, durante o período de maior repressão em decorrência da ditadura, se mantinha no bispado um religioso de ideias progressistas, entrando em conflitos com o Estado. Já no momento de abertura política no país, nas cidades pertencentes a diocese de Viana se sustentou no bispado um religioso totalmente fechado para as ideias de seu antecessor, compartilhando de repressões e agindo como ditador na diocese.

\section{REFERÊNCIAS}

AGAMBEN, Giorgio. Estado de Exceção. São Paulo: Boitempo, 2004.

ALMEIDA. Alfredo Wagner Berno. Autonomia e Mobilização Política dos Camponeses no Maranhão: um estudo sobre as formas de organização dos trabalhadores rurais do Maranhão nas últimas três décadas, história e documentos. Rio de Janeiro: [s.n], 1981.

ARNS, Paulo Evaristo. Brasil: nunca mais. 28. ed. Petrópolis, RJ: Vozes, 1996.

ASSELIN, Victor. Grilagem: corrupção e violência em terras do Carajás. Imperatriz-MA: Ética: 2009.

AZEVEDO, Dermi. Travessias Torturadas: direitos humanos e ditadura no Brasil 1964-1985. Natal: Offset Editora, 2012.

BAUER, Caroline Silveira. Avenida João Pessoa, 20150 - 3 Andar: terrorismo de Estado e ação de polícia política do Departamento de Ordem Política e Social do Rio Grande do Sul (1964-1982). 2006, 282 f. Dissertação ( Mestrado em História) - Universidade Federal do Rio Grande do Sul, Porto Alegre, 2006.

BORGES, Arleth Santos. PT Maranhão 1982- 1992: origens, organização e governos municipais. São Luís: EDUFMA, 2008

BOURDIEU, Pierre. O Poder Simbólico. 15. ed. Rio de Janeiro: Bertrand Brasil, 2011. 
. A Economia das Trocas Linguística: o que falar quer dizer. São Paulo: Editora da Universidade de São Paulo, 2008.

.Compreender. In: BOURDIEU, Pierre (Org.). A Miséria do Mundo. Petrópolis: Vozes, 2007. p. 693- 732.

.Questões de Sociologia. Lisboa: Fim de Século, 2003.

CARVALHO, José Murilo. Cidadania no Brasil: o longo caminho. 6. ed. Rio de Janeiro: Editora Civilização Brasileira, 2004.

CARTILHAS de pastoral social № 01. O que é Pastoral Social? Distrito Federal: CNBB, 2001.

CASTRO, Celso. Pesquisando em Arquivos. Rio de Janeiro: Jorge Zahar Ed, 2008

CELLARD, André. A análise documental. In: POUPART, Jean et al.A Pesquisa Qualitativa: enfoques epistemológicos e metodológicos. Petrópolis, RJ: Vozes, 2008. (p.295-315).

CNBB. Comunicado Mensal. №s 124-125. Janeiro- Fevereiro 1963a.

CNBB. Comunicado Mensal. №s 130-131. Julho- Agosto 1963b.

COSTA, Wagner Cabral da. Sob o signo da morte: o poder oligárquico de Victorino a Sarney. São Luís: EDUFMA, 2006.

ELIAS, Norbert. Introdução à Sociologia Lisboa: Edições 70, 2008.

; SCOTSON, John. L. Os Estabelecidos e os Outsiders: sociologia das relações de poder a partir de uma pequena comunidade. Rio de Janeiro: Jorge Zahar Editor, 2000.

.O processo Civilizador: formação do estado e civilização. Vol. 2. Rio de Janeiro: Zahar, 1993

FICO, Carlos. Como eles Agiam: os subterrâneos da ditadura militar: espionagem e polícia política. Rio de janeiro: Record, 2001. 
FLICK, Uwe. Utilização de documentos como dados. In: Porto Alegre: Artmed, 2009 Introdução à Pesquisa Qualitativa. 3ạ ed.

GUTIÉRREZ, Gustavo. Teologia da Libertação: perspectivas. 4. ed. Petrópolis: Vozes, 1983.

HALBWACHS, Maurice. A Memória Coletiva. Paris, França: Edições Vértice, 1990.

KARNAL, Leandro; TATSCH, Flavia Galli Documento e História. A memória evanescente. In: PINSKY, Carla Bassanezi; LUCA, Tania Regina de (orgs.). O historiador e suas Fontes. São Paulo: Contexto, 2009, p. 9-27.

LOPES, Eliane Ramira Sousa Lopes. Igreja e Política: assistencialismo e cidadania na trajetória da Cáritas Maranhão, 2013,147 f. Monografia (Graduação em Ciências Sociais). Universidade Federal do Maranhão, São Luís, 2013.

LEAL, Victor Nunes. Coronelismo, Enxada e Voto: o município e o regime representativo no Brasil. Rio de Janeiro: Nova Fronteira, 1997.

LUNA, Regina Miranda Reis. Impactos dos grandes projetos para as populações camponesas, no Maranhão. Cad. Pesq. São Luís, 2 (1): 57 - 61 Jan/Jun. 1986.

MAINWARING, Scott. A Igreja Católica e a Política no Brasil (1916-1985). São Paulo: Brasiliense, 2004.

MARTINS, Suely Aparecida. Caminhos e Descaminhos da Socialização Política na Pastoral da Juventude: o caso de Londrina. 2000, 146 f. Dissertação (Mestrado em Sociologia) - Instituto de Filosofia e Ciências Humanas, Universidade Estadual de Campinas, 2000.

PASSOS, João Décio. Como a Religião se Organiza: tipos e processos. São Paulo: Paulinas, (2006).

PIEDADE JUNIOR, Heitor. Casa de "Seu Gegê": um pedaço de saudade. Rio de Janeiro: Maanaim Editora, 2005. 
PINTO, Maria Núbia Bonfim. Do Velho ao Novo: política e educação no Maranhão. 1982, 222 f. Dissertação (Mestrado em Educação). Fundação Getúlio Vargas, Rio de Janeiro, 1982.

POUPART, Jean. A entrevista de tipo qualitativo: considerações epistemológicas, teóricas e metodológicas. In: POUPART, Jean et al. A Pesquisa Qualitativa: enfoques epistemológicos e metodológicos. Petrópolis, RJ: Vozes, 2008. (p. 215-253).

PORTO. Márcio de Souza. Dom Delgado na Igreja de seu tempo (1963 -1969). 2007, 205 f. Dissertação (Mestrado em História Social) - Universidade Federal do Ceará, Fortaleza/ CE, 2007.

RAPÔSO, Maria da Conceição Brenha. Movimento de Educação de Base - MEB: discurso e prática - 19611967. 1982, 205 f. Dissertação ( Mestrado em Educação) - Fundação Getúlio Vargas, Rio de Janeiro, 1982.

SCHERER- WARREN, Ilse. Redes de Movimentos Sociais. São Paulo: Edições Loyola. 2. ed., 1996.

SEMERARO, Gionavi. A Primavera dos Anos 60: a geração de Betinho. São Paulo: Edições Loyola, 1994.

SERBIN. Kenneth P. Diálogos na Sombra: bispos e militares, tortura e justiça social na ditadura. São Paulo: Companhia das Letras, 2001. 